\title{
SISTEM INFORMASI MANAJEMEN DATA PENDUDUK DI KANTOR DESA HATEBICARA KABUPATEN HALMAHERA BARAT
}

\section{MANAGEMENT INFORMATION SYSTEM. POPULATION DATA IN THE HATEBICARA VILLAGE OFFICE WEST HALMAHERA DISTRICT}

\author{
Nadia Arizha Marasabessy ${ }^{1}$, Sabria Sangaji ${ }^{2}$, Muharto $^{3}$, Yuslinah Nurdiyani ${ }^{4}$ \\ ${ }^{1,2,3}$ Program Studi Manajemen Informatika, ${ }^{4}$ Program Studi Teknik Komputer \\ Politeknik Sains dan Teknologi Wiratama Maluku Utara \\ nadiaarizham@yahoo.com
}

\begin{abstract}
Abstrak
Kantor Desa Hatebicara terletak di Halmahera Barat Provinsi Maluku Utara, tepatnya di jln. Ki hajar dewantara, Desa Hatebicara, Halmahera Barat. Sistem informasi pendataan penduduk menggunakan metode prototyping berbasis web pada kantor desa Hate bicara Halmahera Barat membuat sistem pengolahan data penduduk dengan cepat dan akurat. Metode analisis sistem menggunakan metode analisis terstruktur, serta pengembangannya menggunakan metode Prototype, sistem ini dirancang dengan Flowchart, DFD (data flow diagram), ERD (entity relationship diagram) dan dibuat menggunakan bahasa pemrograman HTML, CSS, PHP, Jquery, Javascript serta Database MySQL, dengan adanya aplikasi sistem informasi pendataan penduduk diharapkan kegiatan dalam pengolahan data kependudukan bisa jadi lebih efektif dan efisien, sehingga hasil laporan data penduduk tidak terjadi kesalahan dan mempermudah petugas kantor desa dalam mengolah data kependudukan.
\end{abstract}

Kata kunci: Sistem, Informasi, pendataan penduduk, Website.

\begin{abstract}
The village of Hatebicara Village is located in West Halmahera, North Maluku Province, precisely on Jl. Ki Hajar Dewantara, village hate talking, western Halmahera. Processing of data collection at this Sat hate village office still uses a conventional/manual system and has not utilized a computerized system to carry out its work activities, while data processing is done to obtain the required reports. This research aims to create a system that can present computed data processing. System analysis method uses a structured analysis method, and its development uses Prototype method, this is a system designed with tools Flowchart, DDF (data flow diagram), ERD (entity relationship diagram) and made using HTML, CSS, PHP, jquery, javascript and programming languages. MySQL database, with the application of population data information system by utilizing this information technology, it is expected that activities in population data processing can be more effective and efficient so that the results of population data reports do not occur and facilitate village office officers in processing population data.
\end{abstract}

Keywords: Information Systems, population data collection, Website. 


\section{PENDAHULUAN}

Sistem informasi data penduduk telah banyak dikembangkan untuk memenuhi pelayanan pemerintah kepada masyarakat. Berbagai media yang telah digunakan dalam perkembangnya mulai dari web, desktop dan yang lainnya untuk diterapkan pada sistem informasi data penduduk.

Pendataan penduduk merupakan sub penting dari kependudukan Negara, hal ini bertujuan untuk membangun penyelenggaraan penduduk sebaik mungkin dan bertujuan untuk memberi manfaat dalam perbaikan pemerintahan dan pembangunan.

Sistem yang berjalan Kantor Desa Hate Bicara Halmahera Barat dalam pendataan penduduk masih menggunakan sistem konversional/manual yaitu masih menggukan microsoft office excel untuk menginput data. seperti pencatatan data penduduk, pendaftaran data penduduk, proses data penduduk yang tidak didokumentasi dengan baik dan dapat mengakibatkan data menjadi tidak vailid, yang dalam pembuatannya mempunyai tingkat efektifitas serta efisiensi yang tergolong lemah, dan sering mengalami kesulitan dalam pengolahan data penduduk dan laporannya. Hal tersebut dikerenakan dalam penyimpanan data-data tersebut berupa arsip juga masih ditumpuk dalam lemari sehingga memerlukan waktu yang lama dalam hal pencarian data untuk pengecekan data itu sendiri dan juga sistem keamananan yang tidak ada sehingga banyak data yang sering hilang

Dengan adanya sistem yang memanfaatkan teknologi informasi yang akan membantu proses pendataan penduduk pada Kantor Desa Hate Bicara Halmahera Barat terutama pada proses pendataan penduduk yang memerlukan kecermatan dan ketelitian tinggi. Sehingga dalam waktu yang singkat pembuatan laporan data penduduk tersebut diatas dapat meminimalkan kesalahan yang mungkin terjadi dan dapat memberikan laporan secara cepat dan tepat.

Berdasarkan uraian diatas serta manfaat yang besar dari sistem informasi pendataan penduduk untuk membantu instansi pemerintah dalam menghitung angka kepadatan penduduk pada suatu Desa maka penulis bermaksud merancang sebuah sistem Informasi berbasis web.

\section{Rumusan Masalah}

Berdasarkan latar belakang diatas, maka dirumuskan masalah sebagai berikut : Bagaimana merancang sistem informasi pendataan penduduk menggunakan metode prototyping berbasis web pada Kantor Desa Hatebicara Halmahera Barat?

\section{LANDASAN TEORI}

Konsep dasar Sistem

Menurut Tata Sutabri (2012) Mengemukakan pada dasarnya sistem adalah sekelompok unsur yang erat hubungannya satu dengan yang lain, yang berfungsi bersama-sama untuk mencapai tujuan tertentu.

\section{Pengertian Informasi}

Menurut Yakub (2012) Informasi adalah data yang di olah menjadi bentuk lebih berguna dan lebih berarti bagi yang menerimanya.

\section{Pengertian Sistem Informasi}

Menurut Yakub (2012) Sistem informasi (Information System) merupakan kombinasi teratur dari orang-orang, perangkat keras, perangkat lunak, jaringan komunikasi, dan sumber daya data yang mengumpulkan, mengubah, menyebarkan informasi dalam sebuah organisasi. 


\section{Pengertian Pendataan Penduduk}

Secara umum menurut Biro Pusat Statistik pengertian pendataan adalah proses pembuktian yang ditemukan dari hasil penelitian yng dapat dijadikan dasar kajian atau pendapat. Secara teknis pengertian pendataan adalah proses yang lebih berkaitan dengan pengumpulannya secara empiris. Menurut penulis pendataan dapt diartikan sebagai proses pembuktian dari hasil penelitian dan lebih dikaitkan dengan pengumpulan secara empiris ( ULFA PAUZIAH, 2013).

\section{Pengertian Prototipyng}

Menurut Yuhefizar (2012)

Prototyping adalah salah satu metode pengembangan perangat lunak yang banyak digunakan. Dengan metode prototyping ini pengembang dan pelanggan dapat saling berinteraksi selama proses pembuatan sistem.

\section{Pengertian HTML}

Menurut Sibero (2012) HTML (Hyper Text Markup Language) adalah bahasa yang digunakan pada dokumen web sebagai bahasa untuk pertukaran dokumen web.

\section{Pengertian CSS}

Menurut Kurniawan (2012) Menjelaskan bahwa CSS atau Cascading Style Sheets adalah sebuah dokumen yang berisi aturan yang digunakan untuk memisahkan isi dengan layout dalam halaman-halaman web yang dibuat.

\section{Pengertian PHP}

Menurut Sidik (2012) PHP merupakan secara umum dikenal sebagai bahasa pemrograman script-script yang membuat document HTML secara on the fly yang dieksekusi di server web, document HTML yang dihasilkan dari suatu aplikasi bukan document HTML yang dibuat dengan menggunakan editor teks atau editor HTML.

\section{Pengertian MySQL}

Menurut Sidik

Mengemukakan bahwa MySQL merupakan software database yang termasuk paling populer di lingkungan Linux, kepopuleran ini karena ditunjang karena performsasi query dari databasenya yang saat itu bisa dikatakan paling cepat, dan jarang bermasalah.

\section{Pengertian Flowchart}

Menurut yakub (2012:37) bagan alir program (flowchart) merupakan bagan alir yang mirip dengan bagan alir sistem, yaitu untuk menggambarkan prosedur di dalam sistem"

\section{Pengertian Data flow Diagram ( DFD )}

Menurut Tata Sutabri (2012:117), Data Flow Diagram adalah suatu network yang menggambarkan suatu sistem automat atau komputerisasi, manualisasi, atau gabungan dari keduanya, yang penggambaranya disusun dalam bentuk kumpulan komponen sitem yang saling berhubungan sesuai aturan mainya.

\section{Pengertian Entity RelationShip Diagram (ERD)}

$E R D$ ini merupakan model konseptual yang dapat mendeskripsikan hubungan antara file yang digunakan untuk memodelkan struktur data serta hubungan antara data (Yakub, 2012:68).

\section{METODE PENELITIAN}

Teknik pengumpulan data merupakan cara yang digunakan peneliti untuk mendapatkan data dalam suatu penelitian. 
Pada penelitian ini peneliti menggunakan teknik pengumpulan data dengan cara observasi, dokumentasi, dan wawancara.

1. Observasi

Observasi merupakan suatu teknik yang digunakan untuk mengumpulkan data dengan cara melakukan pengamatan secara langsung terkait dengan pendataan penduduk pada Kantor Desa Hatebicacra Halmahera Barat yang dijadikan tempat penelitian.

2. Wawancara

Wawancara merupakan salah satu teknik untuk mengumpulkan data dengan cara menanyakan secara langsung kepada pihak yang berkaitan dengan Judul penelitian.

3. Dokumentasi

Dokumentasi adalah suatu teknik pengumpulan data dengan cara mengumpulkan semua hal yang diperlukan yang dapat menunjang keberhasilan penelitian pada bidang pendataan penduduk pada Kantor Desa Hate Bicara Halmahera Barat.

\section{Alat dan Bahan yang digunakan}

Alat dan bahan pendukung yang digunakan diantaranya sebagai berikut :

a. Sofware yang digunakan adalah :

1. Sistem operasianal windows 7 ultimate digunakan sebagai sistem operasi dalam penelitian ini.

2. Microsoft office word 2007 digunakan untuk penyusun proposal dalam penelitian ini.

3. Microsoft Visio 2007 untuk membuat gambar alur sistem.

4. Notepad++ dan Subliment text digunakan sebagai alat editor dalam merancang bahasa pemrograman website.
5. CSS, PHP, HTML, JQuery, JavaScript digunakan sebagai bahasa pemrograman yang dipakai dalam website.

b. Hadware yang digunakan adalah :

1. Laptop Acer Aspire one Series

2. Hardisk $500 \mathrm{~GB}$

3. Flashdisk Sandiks 16 GB

4. Printer Canon Ip2770

5. Mouse

\section{Analisa Sistem yang Berjalan}

Sistem yang berjalan Kantor Desa Hate Bicara Halmahera Barat dalam pendataan penduduk masih menggunakan sistem konversional/manual yaitu masih menggukan microsoft office excel untuk menginput data dan dan membuat laporan, penyimpanan data-data tersebut berupa arsip juga masih ditumpuk dalam lemari sehingga memerlukan waktu yang lama dalam hal pencarian data untuk pengecekan data itu sendiri.

Adapun sistem yang berjalan pada Kantor Desa Hate Bicara Halmahera Barat tentang pendataan pendududuk dapat di lihat pada gambar berikut ini :

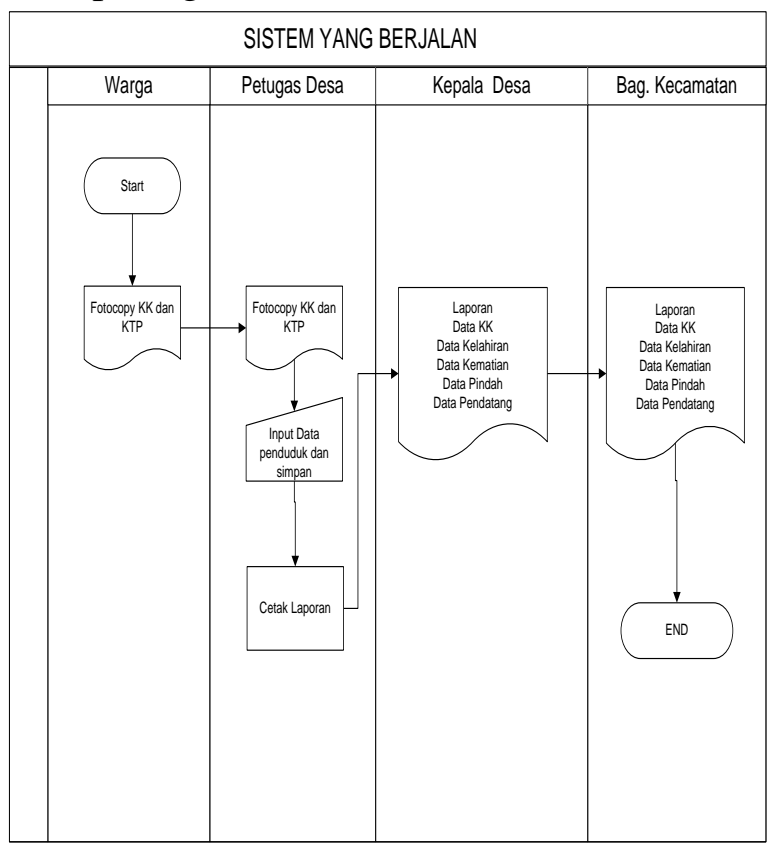

Gambar 1. Sistem yang berjalan 


\section{Rancangan System yang Diusulkan}

Berdasarkan kelemahan-kelemahan yang terdapat pada sistem yang berjalan, maka penulis mengusulkan sistem yang berbasis web, Sistem Informasi Pendataan Penduduk Menggunakan Metode Prototyping Berbasis Web Pada Kantor Desa Hate Bicara Halmahera Barat.

Sistem yang baru ini diharapkan dapat membantu instansi pemerintah dalam menghitung angka kepadatan penduduk pada suatu desa, Khususnya pada Desa Hate Bicara Halmahera Barat.

Rancangan Sistem yang di usulkan merupakan sistem yang baru dapat di tampilkan pada gambar flowchart Sebagai berikut :

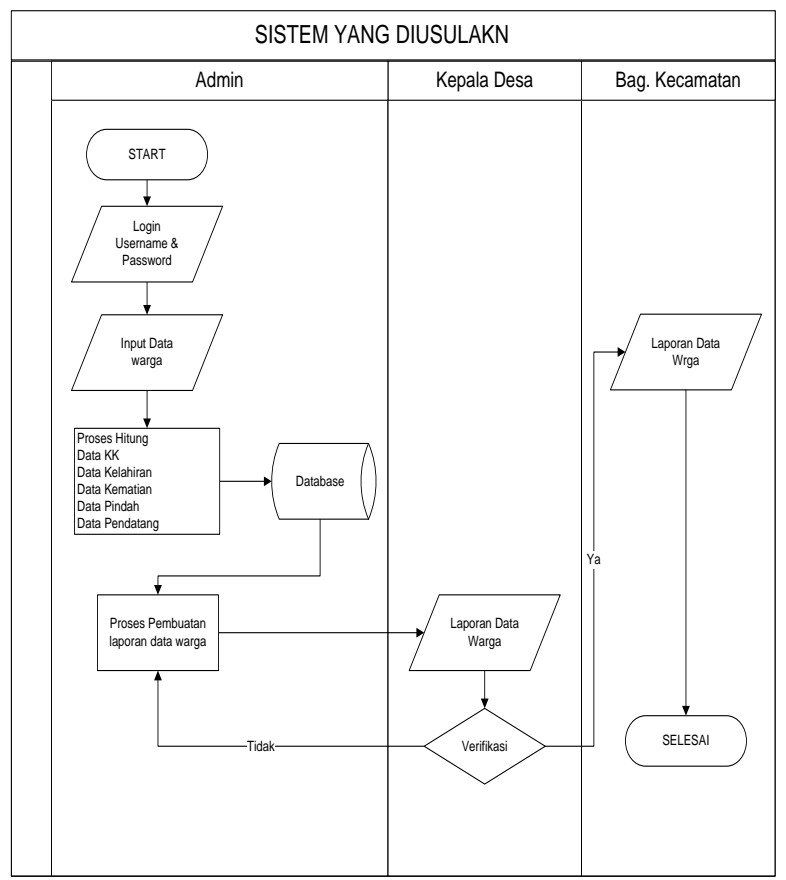

Gambar 2. Flowchart Sistem Yang Diusulkan

\section{Kebutuhan Fungsional}

Kebutuhan fungsional adalah kebutuhan - kebutuhan yang memiliki keterkaitan langsung dengan sistem. Kebutuhan fungsional dari sistem ini adalah :

a. Admin bisa melihat, menambah, mengubah dan menghapus data warga. b. Admin bisa melihat, menambah, mengubah dan menghapus data kartu keluarga.

c. Admin bisa melihat, menambah, mencetak data pendatang.

d. Admin bisa melihat, menambah, mencetak data pindah.

e. Admin bisa melihat, menambah, mencetak data kematia.

f. Admin bisa melihat, menambah, mencetak data kelahiran.

g. Admin bisa mengatur ulang atau merubah nama dan password.

h. logout atau keluar dari system.

\section{Kebutuhan Non-Fungsional}

Adapun Kebutuhan Non-Fungsional tersebut sebagai berikut:

a. Sistem dijalankan pada Windows 10 Profesional 64 Bit.

b. RAM dengan kapasitas minimal 4 GB.

c. Bahasa Pemrograman digunakan HTML, CSS, PHP, MySQL.

d. System diujikan pada Browser Mozilla dengan localhost pada XAMPP

\section{Kebutukan perangkat lunak}

Ada beberapa perangkat lunak yang harus terinstal dalam sistem operasi komputer untuk menjalankan sistem yang akan dibuat, diantaranya adalah:

a. Xampp V. 3. 2.2 sebagai web server

b. Sublimetext 3 sebagai edit source code program.

c. Window7 sebagai sismtem operasi pada leptop

\section{PERANCANGAN SISTEM \\ Perancangan Tabel Database \\ Tabel Data Login}

Tabel 1 : Tabel Warga 


\begin{tabular}{|c|c|c|c|}
\hline File Name & $\begin{array}{l}\text { Data } \\
\text { Type }\end{array}$ & $\begin{array}{l}\text { File } \\
\text { Size }\end{array}$ & Description \\
\hline id_warga * & int & 11 & id_pendatang \\
\hline nik_warga & varchar & 16 & nik_pendatang \\
\hline nama_warga & varchar & 45 & nama_pendatang \\
\hline $\begin{array}{l}\text { tempat_lahir } \\
\text { _warga }\end{array}$ & varchar & 30 & $\begin{array}{l}\text { tempat_lahir_pen } \\
\text { datang }\end{array}$ \\
\hline $\begin{array}{l}\text { tempat_lahir } \\
\text { _warga }\end{array}$ & varchar & 30 & $\begin{array}{l}\text { tempat_lahir_pen } \\
\text { datang }\end{array}$ \\
\hline $\begin{array}{l}\text { tanggal_lahir } \\
\text { _warga }\end{array}$ & date & - & $\begin{array}{l}\text { tanggal_lahir_pen } \\
\text { datang }\end{array}$ \\
\hline $\begin{array}{l}\text { jenis_kelami } \\
\text { n_warga }\end{array}$ & $\begin{array}{l}\text { enum('L', } \\
\text { 'P') }\end{array}$ & - & $\begin{array}{l}\text { jenis_kelamin_pe } \\
\text { ndatang }\end{array}$ \\
\hline $\begin{array}{l}\text { alamat_ktp_ } \\
\text { warga }\end{array}$ & text & & $\begin{array}{l}\text { alamat_ktp_pend } \\
\text { atang }\end{array}$ \\
\hline $\begin{array}{l}\text { alamat_warg } \\
\text { a }\end{array}$ & text & & $\begin{array}{l}\text { alamat_pendatan } \\
\mathrm{g}\end{array}$ \\
\hline $\begin{array}{l}\text { desa_kelurah } \\
\text { an_warga }\end{array}$ & varchar & 30 & $\begin{array}{l}\text { desa_kelurahan_p } \\
\text { endatang }\end{array}$ \\
\hline $\begin{array}{l}\text { kecamatan_ } \\
\text { warga }\end{array}$ & varchar & 30 & $\begin{array}{l}\text { kecamatan_penda } \\
\text { tang }\end{array}$ \\
\hline $\begin{array}{l}\text { kabupaten_k } \\
\text { ota_warga }\end{array}$ & varchar & 30 & $\begin{array}{l}\text { kabupaten_kota_ } \\
\text { pendatang }\end{array}$ \\
\hline $\begin{array}{l}\text { provinsi_war } \\
\text { ga }\end{array}$ & varchar & 30 & $\begin{array}{l}\text { provinsi_pendata } \\
\text { ng }\end{array}$ \\
\hline $\begin{array}{l}\text { negara_warg } \\
\text { a }\end{array}$ & varchar & 30 & $\begin{array}{l}\text { negara_pendatan } \\
\mathrm{g}\end{array}$ \\
\hline $\begin{array}{l}\text { agama_warg } \\
\text { a }\end{array}$ & $\begin{array}{c}\text { enum('Isl } \\
\text { am', } \\
\text { 'Kristen', } \\
\text { 'Katholik' } \\
\text {, 'Hindu', } \\
\text { 'Budha', } \\
\text { 'Konghuc } \\
\text { u') }\end{array}$ & - & agama_pendatang \\
\hline $\begin{array}{l}\text { pendidikan_t } \\
\text { erakhir_war } \\
\text { ga }\end{array}$ & varchar & 20 & $\begin{array}{l}\text { pendidikan_terak } \\
\text { hir_pendatang }\end{array}$ \\
\hline $\begin{array}{l}\text { pekerjaan_w } \\
\text { arga }\end{array}$ & varchar & 20 & $\begin{array}{l}\text { pekerjaan_pendat } \\
\text { ang }\end{array}$ \\
\hline $\begin{array}{l}\text { status_perka } \\
\text { winan_warg } \\
\text { a }\end{array}$ & $\begin{array}{c}\text { enum('K } \\
\text { awin', } \\
\text { 'Blm }\end{array}$ & - & $\begin{array}{l}\text { status_perkawina } \\
\text { n_pendatang }\end{array}$ \\
\hline
\end{tabular}

\begin{tabular}{|l|c|l|l|}
\hline & Kawin') & & \\
\hline status_warga & $\begin{array}{c}\text { enum('Te } \\
\text { tap', } \\
\text { 'Kontrak' } \\
\text { ) }\end{array}$ & - & status_pendatang \\
\hline updated_at & $\begin{array}{c}\text { timestam } \\
\text { p }\end{array}$ & - & updated_at \\
\hline
\end{tabular}

Tabel warga has keluarga

Tabel 2: warga has keluarga

\begin{tabular}{|l|c|c|l|}
\hline File Name & $\begin{array}{c}\text { Data } \\
\text { Type }\end{array}$ & $\begin{array}{c}\text { File } \\
\text { Size }\end{array}$ & \multicolumn{1}{|c|}{ Description } \\
\hline id_warga & Int & 11 & id_warga \\
\hline id_keluarga & Int & 11 & id_keluarga \\
\hline
\end{tabular}

\section{Diagram Konteks}

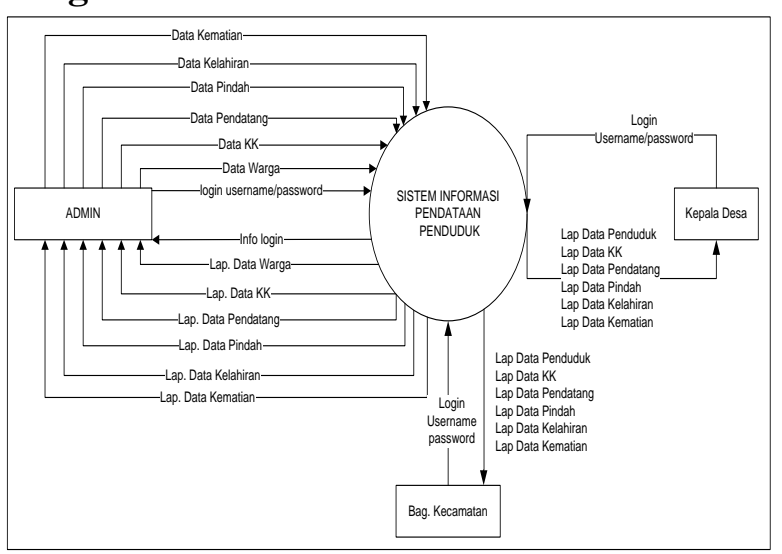

Gambar 3. Diagram Konteks

\section{DFD Level 0}

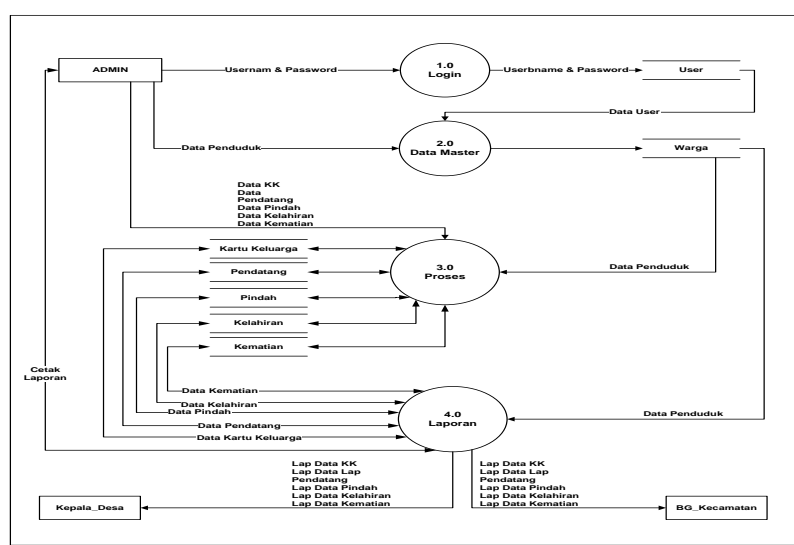

Gambar 4. Diagram Level 0

ERD Relasi Tabel 
Entity Relationship Diagram atau yang biasa disingkat ERD merupakan rancangan model database relasi antar entity dan objek, berikut merupakan hasil rancagan ERD relasi tabel

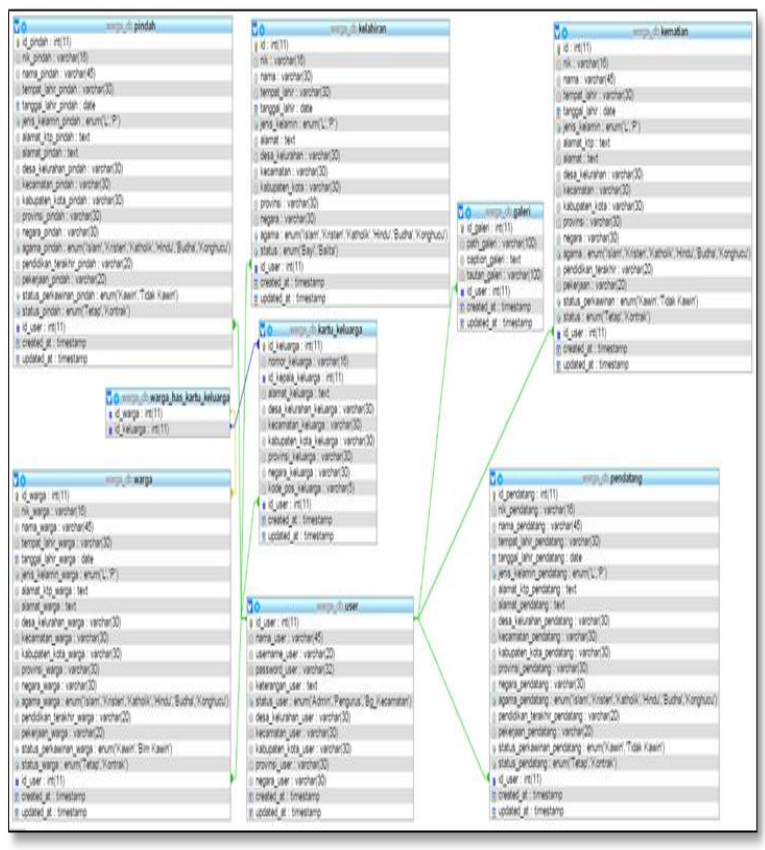

Gambar 5. Relasi Tabel

\section{Entity Relationship Diagram (ERD)}

Notasi

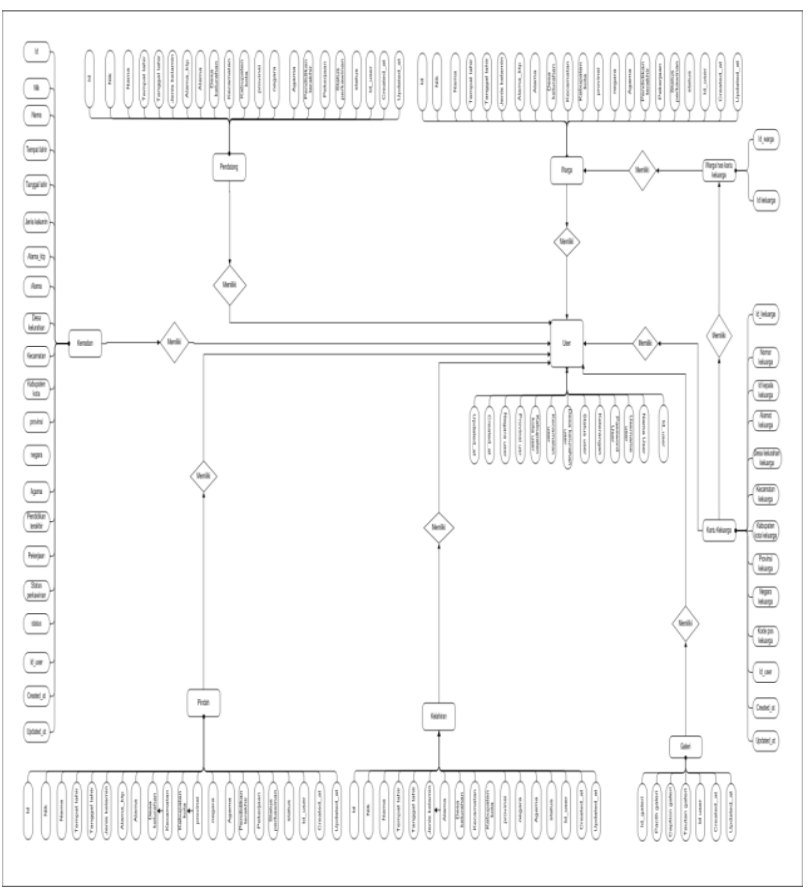

Gambar 6. Erd Notasi
Implementasi sistem merupakan hasil perancangan dan desain dari aplikasi pendataan penduduk berbasis web yang telah dibuat diatas. Di dalam implemtasi sistem ini nantinya juga akan dijelaskan langkah-langka penggunaan dari tiap-tiap menu yang ada pada aplikasi pendataan penduduk tersebut tersebut

\section{Halaman Menu Login}

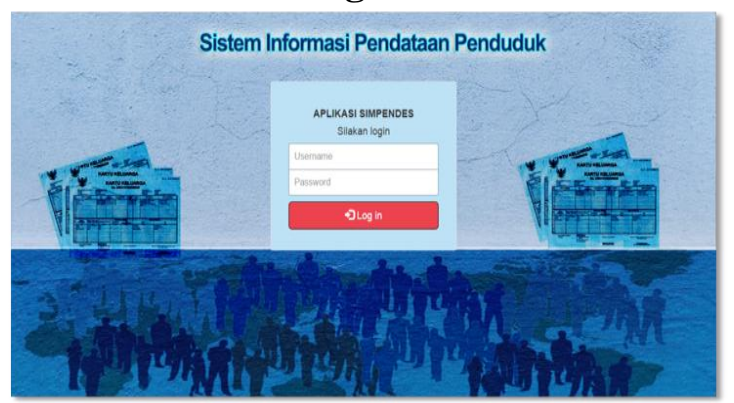

Gambar 7. Menu Login

\section{Halaman Menu Utama Admin}

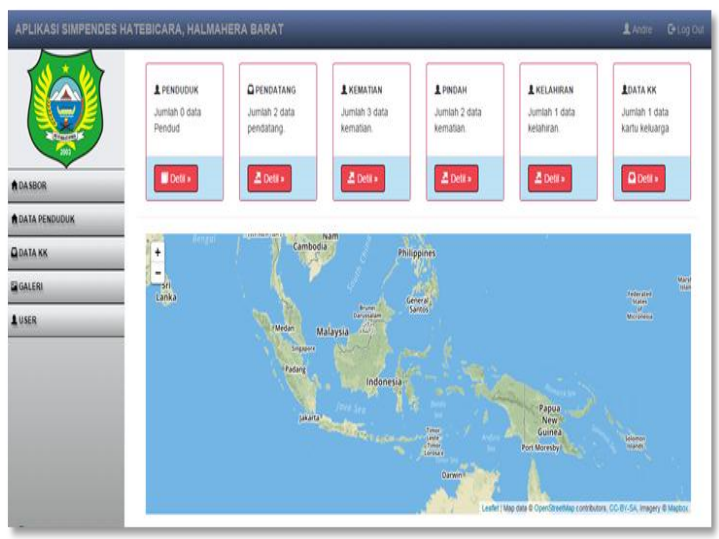

Gambar 8. Menu Utama Admin

\section{Halaman Admin Input Data warga}

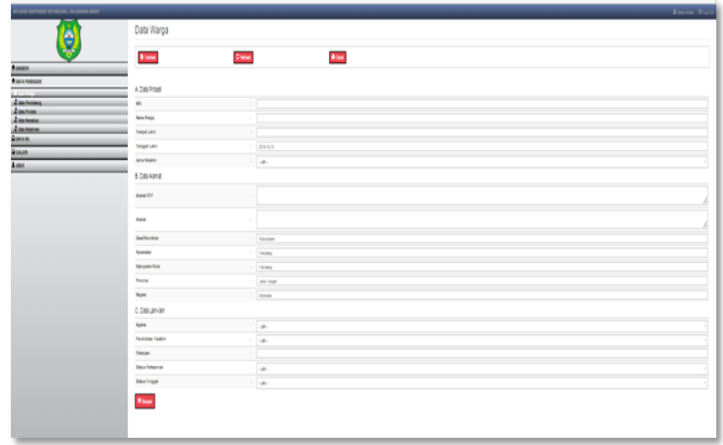

Gambar 9. Admin Input Data Warga

\section{IMPLEMENTASI SISTEM}


Halaman Menu Admin Input Data
Pendatang

\section{Pendatang}

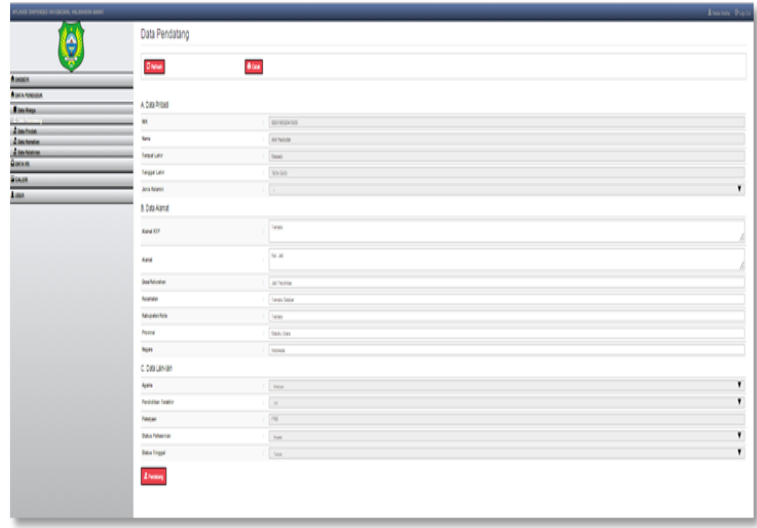

Gambar 10. Admin Input Data Pendatang

Halaman Menu Admin Input Data

Pindah

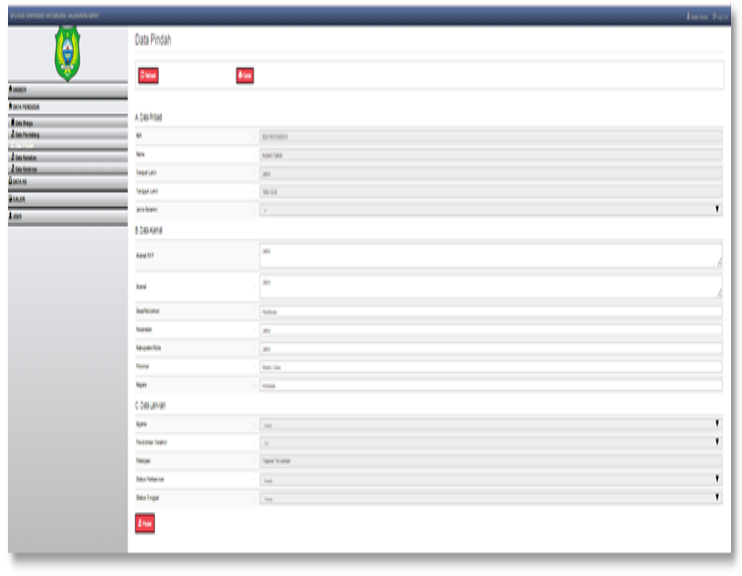

Gambar 11. Admin Input Data Pindah

Halaman Menu Laporan Data Warga

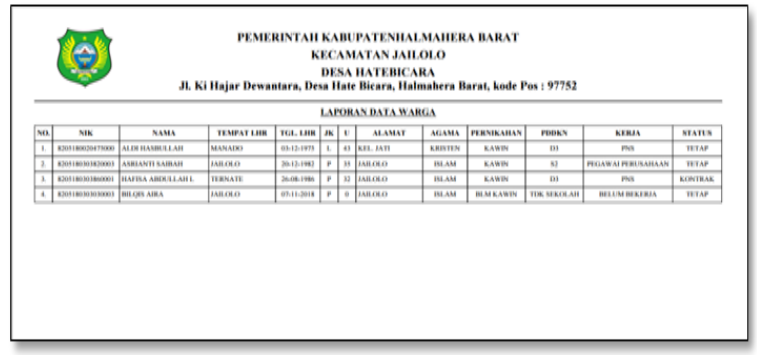

Gambar 12. Menu Laporan Data Warga

\section{Pengujian Sistem Blackbox}

Tabel 3. Tabel Pengujian Sistem

\begin{tabular}{|c|c|c|c|c|c|c|}
\hline $\begin{array}{l}\mathbf{N} \\
\mathbf{0}\end{array}$ & $\begin{array}{l}\text { Antar } \\
\text { Muka }\end{array}$ & $\begin{array}{c}\text { Uji } \\
\text { Coba }\end{array}$ & $\begin{array}{c}\text { Status } \\
\text { Aplikas } \\
\text { i }\end{array}$ & $\begin{array}{l}\text { Skenari } \\
\text { o } \\
\text { Penguji } \\
\text { an }\end{array}$ & $\begin{array}{c}\text { Hasil } \\
\text { yang di } \\
\text { harapk } \\
\text { an }\end{array}$ & $\begin{array}{c}\text { Hasil } \\
\text { Penguj } \\
\text { ian }\end{array}$ \\
\hline
\end{tabular}

\begin{tabular}{|c|c|c|c|c|c|c|}
\hline 1 & $\begin{array}{l}\text { Tampil } \\
\text { an } \\
\text { Login } \\
\text { Admin, } \\
\text { Keapala } \\
\text { Desa } \\
\text { dan Bg. } \\
\text { Kecama } \\
\text { tan }\end{array}$ & $\begin{array}{l}\text { Mengu } \\
\text { ji } \\
\text { proses } \\
\text { login }\end{array}$ & $\begin{array}{l}\text { Masuk } \\
\text { menu } \\
\text { utama } \\
\text { Admin, } \\
\text { Keapala } \\
\text { Desa } \\
\text { dan Bg. } \\
\text { Kecama } \\
\text { tan }\end{array}$ & \begin{tabular}{l}
\multicolumn{1}{c}{ Input } \\
userna \\
me dan \\
passwor \\
d dan \\
pilih \\
Status
\end{tabular} & $\begin{array}{l}\text { Berhasi } \\
1 \\
\text { melaku } \\
\text { kan } \\
\text { validasi }\end{array}$ & $\begin{array}{l}\text { Berhasi } \\
1 \text { masuk } \\
\text { ke } \\
\text { Menu } \\
\text { utama }\end{array}$ \\
\hline 2 & $\begin{array}{l}\text { Tampil } \\
\text { an } \\
\text { utama } \\
\text { admin }\end{array}$ & $\begin{array}{l}\text { Mengu } \\
\text { ji } \\
\text { semua } \\
\text { menu } \\
\text { yang } \\
\text { terdapa } \\
\text { t pada } \\
\text { halama } \\
n \text { web }\end{array}$ & $\begin{array}{l}\text { Tampil } \\
\text { an } \\
\text { halama } \\
\mathrm{n} \text { web } \\
\text { sudah } \\
\text { terbuka }\end{array}$ & $\begin{array}{l}\text { Klik } \\
\text { menu } \\
\text { yang } \\
\text { tersedia }\end{array}$ & $\begin{array}{l}\text { Menu } \\
\text { yang } \\
\text { dipilih } \\
\text { dapat } \\
\text { membu } \\
\text { ka } \\
\text { halama } \\
\mathrm{n}\end{array}$ & $\begin{array}{l}\text { Menu } \\
\text { yang } \\
\text { dipilih } \\
\text { dapat } \\
\text { membu } \\
\text { ka } \\
\text { halama } \\
\text { n }\end{array}$ \\
\hline 3 & $\begin{array}{l}\text { Tampil } \\
\text { an } \\
\text { Kelola } \\
\text { data } \\
\text { warga }\end{array}$ & $\begin{array}{l}\text { Mengu } \\
\text { ji untuk } \\
\text { mengin } \\
\text { put } \\
\text { data } \\
\text { warga }\end{array}$ & $\begin{array}{l}\text { Masuk } \\
\text { pada } \\
\text { input } \\
\text { data } \\
\text { warga }\end{array}$ & $\begin{array}{l}\text { Masuk } \\
\text { kan } \\
\text { data } \\
\text { yang } \\
\text { berkaita } \\
\mathrm{n} \\
\text { dengan } \\
\text { data } \\
\text { warga }\end{array}$ & $\begin{array}{l}\text { Menu } \\
\text { yang } \\
\text { dipilih } \\
\text { dapat } \\
\text { mengin } \\
\text { put data } \\
\text { warga }\end{array}$ & $\begin{array}{l}\text { Menu } \\
\text { yang } \\
\text { dipilih } \\
\text { dapat } \\
\text { mengin } \\
\text { put } \\
\text { data } \\
\text { warga }\end{array}$ \\
\hline 4 & $\begin{array}{l}\text { Tampil } \\
\text { an } \\
\text { Kelola } \\
\text { data } \\
\text { pindah }\end{array}$ & $\begin{array}{l}\text { Mengu } \\
\text { ji untuk } \\
\text { mengin } \\
\text { put } \\
\text { data } \\
\text { pindah }\end{array}$ & $\begin{array}{l}\text { Masuk } \\
\text { pada } \\
\text { input } \\
\text { data } \\
\text { pindah }\end{array}$ & $\begin{array}{l}\text { Masuk } \\
\text { kan } \\
\text { data } \\
\text { yang } \\
\text { berkaita } \\
\mathrm{n} \\
\text { dengan } \\
\text { data } \\
\text { pindah }\end{array}$ & $\begin{array}{l}\text { Menu } \\
\text { yang } \\
\text { dipilih } \\
\text { dapat } \\
\text { mengin } \\
\text { put data } \\
\text { pindah }\end{array}$ & $\begin{array}{l}\text { Menu } \\
\text { yang } \\
\text { dipilih } \\
\text { dapat } \\
\text { mengin } \\
\text { put } \\
\text { data } \\
\text { pindah }\end{array}$ \\
\hline 5 & $\begin{array}{l}\text { Tampil } \\
\text { an } \\
\text { Kelola } \\
\text { data } \\
\text { pendata } \\
\text { ng }\end{array}$ & $\begin{array}{l}\text { Mengu } \\
\text { ji untuk } \\
\text { mengin } \\
\text { put } \\
\text { data } \\
\text { pendata } \\
\text { ng }\end{array}$ & $\begin{array}{l}\text { Masuk } \\
\text { pada } \\
\text { input } \\
\text { data } \\
\text { pendata } \\
\text { ng }\end{array}$ & $\begin{array}{l}\text { Masuk } \\
\text { kan } \\
\text { data } \\
\text { yang } \\
\text { berkaita } \\
\mathrm{n} \\
\text { dengan } \\
\text { data } \\
\text { pendata } \\
\text { ng }\end{array}$ & $\begin{array}{l}\text { Menu } \\
\text { yang } \\
\text { dipilih } \\
\text { dapat } \\
\text { mengin } \\
\text { put data } \\
\text { pendata } \\
\text { ng }\end{array}$ & $\begin{array}{l}\text { Menu } \\
\text { yang } \\
\text { dipilih } \\
\text { dapat } \\
\text { mengin } \\
\text { put } \\
\text { data } \\
\text { pendata } \\
\text { ng }\end{array}$ \\
\hline 6 & $\begin{array}{l}\text { Tampil } \\
\text { an } \\
\text { Kelola } \\
\text { data } \\
\text { kelahira } \\
\mathrm{n}\end{array}$ & $\begin{array}{l}\text { Mengu } \\
\text { ji untuk } \\
\text { mengin } \\
\text { put } \\
\text { data } \\
\text { kelahir } \\
\text { an }\end{array}$ & $\begin{array}{l}\text { Masuk } \\
\text { pada } \\
\text { input } \\
\text { data } \\
\text { kelahira } \\
\text { n }\end{array}$ & $\begin{array}{l}\text { Masuk } \\
\text { kan } \\
\text { data } \\
\text { kelahira } \\
\mathrm{n}\end{array}$ & $\begin{array}{l}\text { Menu } \\
\text { yang } \\
\text { dipilih } \\
\text { dapat } \\
\text { mengin } \\
\text { put data } \\
\text { kelahira } \\
\text { n }\end{array}$ & $\begin{array}{l}\text { Menu } \\
\text { yang } \\
\text { dipilih } \\
\text { dapat } \\
\text { mengin } \\
\text { put } \\
\text { data } \\
\text { kelahir } \\
\text { an }\end{array}$ \\
\hline 7 & $\begin{array}{l}\text { Tampil } \\
\text { an } \\
\text { Kelola } \\
\text { data } \\
\text { kematia } \\
\mathrm{n}\end{array}$ & $\begin{array}{l}\text { Mengu } \\
\text { ji untuk } \\
\text { data } \\
\text { kemati } \\
\text { an }\end{array}$ & $\begin{array}{l}\text { Masuk } \\
\text { pada } \\
\text { input } \\
\text { data } \\
\text { kematia } \\
\text { n }\end{array}$ & $\begin{array}{l}\text { Masuk } \\
\text { kan } \\
\text { data } \\
\text { kematia } \\
\text { n }\end{array}$ & $\begin{array}{l}\text { Menu } \\
\text { yang } \\
\text { dipilih } \\
\text { dapat } \\
\text { mengin } \\
\text { put data } \\
\text { kematia } \\
\mathrm{n}\end{array}$ & $\begin{array}{l}\text { Menu } \\
\text { yang } \\
\text { dipilih } \\
\text { dapat } \\
\text { mengin } \\
\text { put } \\
\text { data } \\
\text { kematia } \\
\text { n }\end{array}$ \\
\hline 8 & $\begin{array}{l}\text { Tampil } \\
\text { an } \\
\text { Kelola } \\
\text { data } \\
\text { kartu } \\
\text { Keluarg } \\
\text { a }\end{array}$ & $\begin{array}{l}\text { Mengu } \\
\text { ji untuk } \\
\text { mengin } \\
\text { put } \\
\text { data } \\
\text { kartu } \\
\text { Keluar } \\
\text { ga }\end{array}$ & $\begin{array}{l}\text { Masuk } \\
\text { pada } \\
\text { input } \\
\text { data } \\
\text { kartu } \\
\text { Keluarg } \\
\text { a }\end{array}$ & $\begin{array}{l}\text { Masuk } \\
\text { kan } \\
\text { data } \\
\text { kartu } \\
\text { Keluarg } \\
\text { a }\end{array}$ & $\begin{array}{l}\text { Menu } \\
\text { yang } \\
\text { dipilih } \\
\text { dapat } \\
\text { mengin } \\
\text { put data } \\
\text { kartu } \\
\text { Keluarg } \\
\text { a }\end{array}$ & $\begin{array}{l}\text { Menu } \\
\text { yang } \\
\text { dipilih } \\
\text { dapat } \\
\text { mengin } \\
\text { put } \\
\text { data } \\
\text { kartu } \\
\text { Keluar } \\
\text { ga }\end{array}$ \\
\hline
\end{tabular}

Volume 4 Nomor 2 | September 2019 


\begin{tabular}{|c|l|l|l|l|l|l|}
\hline 9 & $\begin{array}{l}\text { Tampil } \\
\text { an } \\
\text { Kelola } \\
\text { data } \\
\text { user }\end{array}$ & $\begin{array}{l}\text { Mengu } \\
\text { ji untuk } \\
\text { mengin } \\
\text { put } \\
\text { data } \\
\text { user }\end{array}$ & $\begin{array}{l}\text { Masuk } \\
\text { pada } \\
\text { input } \\
\text { data } \\
\text { user }\end{array}$ & $\begin{array}{l}\text { Masuk } \\
\text { kan } \\
\text { data } \\
\text { user }\end{array}$ & $\begin{array}{l}\text { Menu } \\
\text { yang } \\
\text { dipilih } \\
\text { dapat } \\
\text { mengin } \\
\text { put data } \\
\text { user }\end{array}$ & $\begin{array}{l}\text { Menu } \\
\text { yang } \\
\text { dipilih } \\
\text { dapat } \\
\text { mengin } \\
\text { put } \\
\text { data } \\
\text { user }\end{array}$ \\
\hline 1 & $\begin{array}{l}\text { Tampil } \\
\text { an } \\
\text { Kelola } \\
\text { data } \\
\text { kematia } \\
\text { n }\end{array}$ & $\begin{array}{l}\text { Mengu } \\
\text { ji untuk } \\
\text { data } \\
\text { kemati } \\
\text { an }\end{array}$ & $\begin{array}{l}\text { Masuk } \\
\text { pada } \\
\text { input } \\
\text { data } \\
\text { kematia } \\
\text { n }\end{array}$ & $\begin{array}{l}\text { Masuk } \\
\text { kan } \\
\text { data } \\
\text { kematia } \\
\text { n }\end{array}$ & $\begin{array}{l}\text { Menu } \\
\text { yang } \\
\text { dipilih } \\
\text { dapat } \\
\text { mengin } \\
\text { put data } \\
\text { kematia } \\
\text { n }\end{array}$ & $\begin{array}{l}\text { Menu } \\
\text { yang } \\
\text { dipilih } \\
\text { dapat } \\
\text { mengin } \\
\text { put } \\
\text { data } \\
\text { kematia } \\
n\end{array}$ \\
& & & & & \\
& & & & & \\
& & & & & \\
\end{tabular}

\section{KESIMPULAN}

1. system informasi manajemn pendataan penduduk menggunakan metode prototyping pada kantor desa hatebicara berbasis web ini dalam mengelolah data penduduk semakin cepat, data tersimpan aman didalam database dan dapat dilihat oleh kepala desa dan petugas kecamatan.

2. Sistem informasi pendataan penduduk pada kantor desa hate bicara berbasis web menggunakan metode prototyping lebih mempermudah peneliti dalam melakukan evaluasi kerja membuat sistem lebih baik dan sesuai kemauan pengguna.

3. Dalam sistem ini pengguna dapat melihat data warga pindah, pendatang, kelahiran dan kematial lebih detail.

\section{Saran}

1. Untuk peneliti berikutnya diharapkan dapat mengembangankan sistem informasi pendataan penduduk menggunakan metode lain yang lebih bagus dan lebih baik dari metode prototyping.

2. Sebaiknya membuat grafik dari peningkatan atau pengurangan penduduk sehingga akan lebih mengetahui perkembangan penduduk.

3. Perlu adanya perluasan fungsi dari sistem ini, misalnya penambahan, data akta kelahiran, data RT, data RW, serta foto dari masing-masing warga.

\section{DAFTAR PUSTAKA}

Betha, Sidik, 2012. Pemrograman Web dengan PHP. Informatika. Bandung.

Kurniawan, B, 2012. Desain Web Praktis dengan CSS. Elex Media Komputindo. Yogyakarta.

Sutabri, T. ( 2012). Analisis Sistem Informasi. Andi. Yogyakarta.

Sibero, A. F.K. (2013). Web Programming Power Pack. Mediakom. Yogyakarta

Yakub (2012). Pengantar Sistem Informasi. Graha Ilmu. Yogyakarta

Yuhefizar, 2012. Cara Mudah Dan Murah Membangun Dan Mengelola Website, Penerbit Graha Ilmu, Surabaya.

One Yunita Fujiyati, Sukadi, Sistem Informasi Pengolahan Data Kependudukan Desa Purwoasri, Journal Speed - Sentra Penelitian Engineering dan Edukasi - Volume 7 No 1 - 2015 - ijns.org.ISSN : 19799330 (Print) - 2088-0154 (Online)

Wisti Dwi Septiani, Sistem Informasi Pengelolaan data Penduduk (Studi Kasus: RT/RW Kelurahan Pondok Kacang Timur). Jurnal Ilmu Pengetahuan Dan Komputer, Vol 4 No 1 Agustus 2018, E-ISSN: 25274864

Yulita, Yakub, Wiyoso, Perancangan Sistem Informasi Data Kependudukan Pada Cluster PT. Alam Sutera Realty Tbk. Jurnal SISFOKOM, Volume 04, Nomor 02, September 2015, ISSN 2301-7988 e-ISSN 2581-0588

Paryanta, Sutariyani, Desi Susilowati, Sistem Informasi Administrasi Kependudukan Berbasis Web Desa Sawahan, IJSE - Indonesian Journal on Software Engineering, Volume 3 No 2 - 2017, ISSN : 2461-0690 